\title{
ALTERNATIF PEWARNAAN PADA KAIN TRADISIONAL ENDEK DENGAN TEKNIK AIR BRUSH
}

\author{
I Made Sukerta ${ }^{1)}$ I Made Legawa ${ }^{2)}$,Eka Martiningsih 3), Anom Adiaksa 4) \\ Dosen Universitas Mahasaras wati Denpasar \\ Dosen Politeknik Negeri Bali
}

\begin{abstract}
ABSTRAK
Endek adalah salah satu kain khas hasil karya tangan orang Bali. Coraknya yang unik dan kental dengan nuansa etnik menjadikan endek banyak digunakan oleh berbagai kalangan, bahkan juga digunakan sebagai seragam para pegawai dinas pemerintahan daerah Bali dan juga pegawai swasta seperti pegawai bank, hotel, travel maupun rumah sakit. Beberapa tahun belakangan, endek juga mendapatkan promosi besar-besaran sehingga namanya menjadi kian terangkat bahkan hingga ke tingkat mancanegara. Patra atau motifyang dituangkan dalam kain ikat atau tenun khas Bali, endek, bukan hanya estetika keindahan semata, namun juga mempunyai pesan yang bercerita (story telling) tentang budaya. Akan tetapi dengan semakin berkembangnya era globalisasi dan perdagangan di aras Internasional (MEA) maka produk-produk tradisional mulai kalah bersaing dari sisi harga. Karena produk luar Bali biasanya memiliki harga yang lebih rendah dibandingkan produk lokal, walaupun dari sisi kualitas produk luar lebih rendah. Kesenjangan dalam hal harga inilah merupakan salah satu kendala dari mitra yaitu Ud. Anugrah dan UD. Artha Dharma. Berkaitan dengan pemecahan masalah tersebut maka pelaksanaan program IbPE (Ipteks Bagi Produk Ekspor) pada tahun pertama ini bertujuan untuk meningkatkan posisi pasar mitra dengan cara memberikan pembinaan pada proses produksi seperti penataan stasiun kerja, dan penambahan desain agar menghasilkan desain yang lebih beragam sehingga pengrajin mampu menual produk secara bersaing di pasaran. Pada pembinaan desain telah dilakukan beberapa diversifikasi desain yang sederhana sehingga dalam proses produksi seperti pemilihan benang, bahan dasar, pewarnaan, dan penenunan lebih sederhana. Hal ini akan berdampak pada biaya produksi yang lebih sedikit, sehingga produk kain endek dapat dijual dengan harga bersaing di pasaran. Selain diversifikasi desain, tim Universitas Mahasaraswati Denpasar juga telah memberikan pendampingan dalam diversifikasi jenis produk secara fungsional, misalnya seperti pembuatan destar, pakaian seragam dan juga sudah menyasar pada aksesoris seperti clutch (dompet dan sandal). Pembinaan pada tahun pertama sudah mendorong UKM mitra mampu bersaing dalam harga dengan produk luar. Pembinaan pada tahun kedua adalah deng an melakukan teknik pewarnaan metode airbrush. Dengan metode ini pewarnaan mampu dilakukan lebih cepat sehingga proses produksi akan dipercepat sampai 2-4 hari kerja.
\end{abstract}

Kata Kunci: Endek, Desain, Diversifikasi, Patra, Pewarnaan

\section{PENDAHULUAN}

Indonesia memiliki ragam budaya yang sangat bervariasi, mulai dari etnis, agama, tradisi, kesenian, sampai pada industri tekstil. Salah Satu kebanggan industry tekstil tradisional Bali adalah kain tenun ikat yang disebut Endek dan
Songket Bali. Jenis kain tenun ini memiliki nilai historis yang adiluhung karena konon setiap perempuan Bali diharuskan memiliki ketrampilan menenun. Keterampilan menenun ini merupakan salah satu persyaratan seorang perempuan Bali dapat melakukan pernikahan. 
Jurnal ABDIMAS, Vol. 10, No. 2, Desember 2017

ISSN: 1979-0953

Tradisi ini kemudian memberikan efek semakin menyebarnya keterampilan menenun masyarakat perempuan Bali, yang kemudian menghasilkan beragam karakter desain di masing-masing daerah di Bali. Setiap kabupaten di Bali memiliki ciri khas desain yang menunjukkan karakter daerah masingmasing. Setiap kabupaten menonjolkan cirri khas daerahnya melalui goresan desain pada setiap lembar kain tenunnya. Keberagaman ini sangat positif dalam menambah khasanah desain dan kebergaman jenis kain tenun Bali. Keberagaman ini akhirnya menghasilkan corak yang sangat variatif sehingga memudahkan konsumen untuk menentukan pilihan. Selain itu persaingan penjualan menjadi sehat karena setiap hasil tenun daerah di Bali memiliki ciri khas.

Seiring dengan perkembangan jaman dan era globalisasi, ternyata kenyamanan penenun tradisional Bali mulai terusik dengan kecanggihan perangkat digital yang mampu mencontoh desain dengan sempurna sehingga banyak penenun bali kalah bersaing. Perangkat digital mampu memproses dengan waktu yang lebih cepat dengan biaya produksi yang lebih rendah, sehingga penenun dengan alat digital lebih cepat proses produksinya dan mampu menjual dengan harga yang lebih murah. Fenomena ini sangat meresahkan penenun tradisional yang ingin tetap mengajegkan desain desain khas Bali yang memiliki kesulitan lebih tinggi dalam pengerjaannya dan finishing produknya.

Selain permasalahan tersebut, penenun tradisional Bali juga sedang mengalami serangan pembajakan desain besar-besaran dari pengrajin luar Bali yang membuat kain endek dengan motif sama dengan proses produksi yang lebih cepat, sehingga harga produk tersebut lebih murah dipasaran, akan tetapi dari sisi kualitas dan nilai seni desain sangat rendah. Kondisi ini sangat mengkhawatirkan keajegan tenun endek dan songket Bali sehingga perlu dilakukan terobosan dengan cara melaksanakan pembinaan secara berkelanjutan kepada penenun endek dan songket Bali melalui program Ipteks bagi Produk Ekspor (IbPE). Program IbPE Unmas Denpasar menyasar dua mitra yaitu UD. Anugrah yang berlokasi di Banjar Minggir desa Gelgel Kelungkung dengan ketua Ibu Ni Ketut Tantri dan UD, Artha Dharma yang berlokasi di Desa Sinabun, Kubu Tambahan Singaraja dengan ketua I Ketut Rajin.

Tujuan dari IbPE pada tahun 2 ini adalah: 1) untuk membina proses produksi agar lebih cepat dengan bantuan alat-alat yang lebih canggih seperti pewranaan dengan teknik airbrush, 2) untuk membantu melakukan diversifikasi jenis produksi agar mampu bersaing dengan produk-produk dari luar Bali.3) memberikan pemahaman manajemen pembukuan berbasis komputer 
Jurnal ABDIMAS, Vol. 10, No. 2, Desember 2017

ISSN: 1979-0953

\section{METODE PELAKSANAAN}

Pelaksanaan program IbPE pada UD Anugrah dan UD Artha Dharma direncanakan berlangsung selama tiga tahun yaitu mulai pelaksanaan tahun 2016 berakhir pada tahun 2018. Dengan kurun waktu pelaksanaan yang cukup lama, maka metode yang diterapkan dalam pemberdayaan ini adalah

\section{Observasi}

Metode observasi dilaksanakan dengan cara langsung melakukan identifikasi dan pendekatan kepada masing-masing mitra untuk menentukan permasalahan yang dihadapi dan mendata dengan cermat strategi solusi dari masing-masing permasalahan yang ditemukan. Sistem pendekatan penentuan masalahn dengan bottom up strategy, yaitu menggali permasalahan dari pihak mitra untuk kemudian dicariakan dan didiskusikan solusi pemecahannya (Ife, 2002).

\section{Participatory Research Action (PRA)}

Metode ini dilaksanakan dengan melibatkan diri secara aktif dalam setiap kegiatan mitra sambil mengamati dan memberikan solusi kepada permasalahan yang ditemukan. Metode ini merupakan pendekatan yang sangat tepat dilkukan untuk memecahkan masalah mitra. PRA merupakan metode yang mengharuskan peneliti atau pelaksana program untuk terlibat langsung dalam seluruh kegiatan mitra, sehingga akan lebih mantap dalam menentukan solusi terhadap pemasalahan mitra. Metode PRA ini sangat tepat untuk digunakan dalam penelitian kualitatif dan pemberdayaan masyarakat.

\section{Focus Group Discussion (FGD)}

Metode diskusi kelompok (FGD) sangat membantu dalam rangka pengambilan data yang dilakukan pada komunitas yang berjumlah banyak. Pelaksanaan FGD akan membantu masing-masing anggota komunitas untuk saling berbagi pengalaman sehingga data yang diperoleh akan lebih lengkap. Di samping itu teknik FGD sangat membantu pelaksana program untuk melakukan identifikasi secara lebih lengkap dengan waktu yang lebih singkat. Teknik FGD sangat sesuai degunakan untuk melakukan observasi awal dan mengetahui peningkatan pemahaman komunitas terhadap kegiatan yang sudah dilaksanakan.

\section{Pelatihan dan Pendampingan}

Metode pendekatan ini dilakukan dengan melibatkan beberapa anggota UKM untuk memahami dan mampraktekkan langsung teknik teknik dalam proses produksi tenun. Prose produksi tersebut meliputi persiapan benang, pewarnaan, desain dan finishing. Pada tahun ke 2 pelaksanaan program ini tim Unmas Denpasar bekerjasama dengan Politeknik Negeri Bali melakukan pelatihan dan pendampingan pewarnaan dengan teknik semprot (Airbrush). Pada pelatihan ini UKM diberikan alat spit dan kompresor serta cara mencampur bahan pewarna tekstil.

Monitoring dan Evaluasi (MONEV) 
Pada pelaksanaan pemberdayaan masyarakat kegiatan monev sangat penrting dialkukan untuk mengukur keberhasilan program yang telah dilaksanakan. Monitoring dan evaluasi dapat dilakukan denga melakukan pre test dan post test, atau dengan melihat langsung perubahan secara kuantitatif dan kualitatti setiap perubahan yang terjadi pada mitra binaan. Monev yang dilakukan bertujuan untuk memastikan bahwa program yang telah dilakasanakan dapata terserap dengan baik oleh mitra sehingga pelaksana ptogram pemberdayaan dapat melakukan rencana program lanjutan. Progres yang dievaluasi adalah 1) peningkatan pemahaman terhadap materi yang diberikan, 2) peningkatan kuantitasdan kualitas produk, 3) peningkayan kapasitas mitra (capacity building), 4) peningkatan omzet penjualan produk, 5) keberlanjutan usaha mitra.

\section{HASIL DAN PEMBAHASAN}

Profil ke dua mitra yang menjadi sasaran pembinaan Ipteks bagi Produk Ekspor Unmas Denpasar berbeda baik dari sisi kapasitas usaha, jumlah produksi, jumlah tenaga kerja, luas jaringan dan omzet. Berdasarkan hal tersebut maka pembinaan dan pemberdayaan yang dilakukan sesuai dengan kebutuhan masingmasing UKM mitra. Beberapa kegiatan pembinaan yang sudah dilaksanakan pada UKM UD. Anugrah dan UD. Artha Darma adalah:
1. Penataan lay out stasiun kerja. Program ini dilaksanakan untuk memenuhi standar keselamatan, keamanan dan kesehatan kerja (K3) bagi tenaga kerja. Program ini sangat penting karena pekerjaan menenun yang dilakukan oleh pekerja sangat mempengaruhi kesehatan pekerja apalagi penenunan lebih banayak dilaksanakan dengan posisi duduk. Apabila posisi kerja tidak diatur sesuai dengan aturan secara ergonomis maka akan sangat menggangu konsentrasi kerja dan produktivitas tenaga kerja untuk berproduksi.

2. Penataan ruang display

Kegiatan penataan ruang display sangat penting dilakukan untuk membuat endek dan songket yang dihasilkan aman dan menambah keindahan produk yang dihasilkan. Di samping itu dengan penataan display yang baik akan menambah kenyamanan pembeli untuk melakukan transaksi dan juga mempermudah UKM untuk melakukan kontrol terhadap keluar dan masuknya barang-barang produksi.

\section{Diversifikasi Desain}

Kegiatan pelatihan desain baru dilaksanakan pada tahap pemahaman teoritis tentang desain dan pendampingan dalam membuat desain dasar yang benar yang sesuai dengan budaya kain tradisional. Pada pendampingan ini juga dilakukan diskusi tentang cara mencegah terjadinya plagiasi desain yang selama ini sangat marak terjadi. 
Pembajakan desain sangat mempengaruhi kreatifitas penenun karena akan sangat berdampak terhadap penurunan omzet penjualan karena plagiator akan memproduksi kain dengan massif karena melakukan produksi secara pabrikasi. Barang produksi dengan cara ini memiliki harga yang jauh lebih murah dari tenun yang dibuat dengan cara manual akan tetapu kualitas sangat rendah.

4. Bantuan alat produksi

Dalam beberapa tahapan produksi masih ditemukan kendala karena keterbatasan alat yang dimiliki. Di UD. Artha Darma karena proses desain relative dilakukan secara manual maka program IbPE Unmas Denpasar sedang mengusahakan alat airbrush yang mampu mempersingkat proses desain terutama pada proses pewranaan benang. Dengan teknik airbrush ini pewarnaan dapat dipersingkat lagi 2 hari kerja. Selain alat airbrush, di UD. Artha Darma sudah juga ada alat "ngeliying" secara mekanik sehingga mampu menampung benang masing-masing 10 buah. Dengan alat ini juga dapat mengurangi jumlah benang yang kusut.

5. Teknik pewarnaan dengan airbrush

Teknik ini merupakan salah satu alternatif pewarnaan tekstil yang efisien walaupun masih jarang dipraktekkan oleh UKM kani tradisional. Padahal menurut Fitinline (2012) teknik dengan pewranaan ini tidak kalah dengan pewarnaan celup malahan variasi warna yang dihasilkan semakin banyak. Dengan pewarnaan teknik semprot ini diharapkan proses produksi kain endek dapat dihemat 2-3 hari. Hal ini tentu saja akan berpengaruh pada ongkos produksi dan harga kain endek.

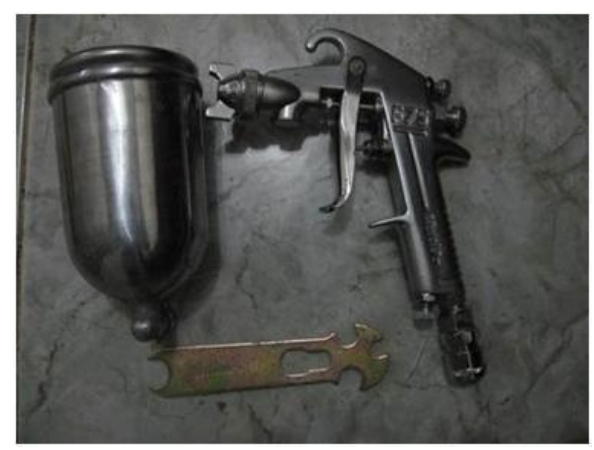

Gambar 1. Alat semprot (Spite) airbrush

\section{KESIMPULAN}

1. Pelaksanaan program IbPE Unmas Denpasar di UD. Anugrah dan Ud. Artha Darma untuk pembiyaan tahun 2017 secara umum sudah dilaksanakan dengan baik. Ke dua mitra saat ini sudah memiliki ketrampilan manajemen berbasis komputer

2. Partisipasi ke dua mitra sangat baik hal ini dapat dilihat dari antusiasme UKM dalam menerima pembinaan yang dilaksanakan dan dengan tekun mengikuti pelatihan penggunaan alat alat pendukung pembinaan

3. Pemahaman dan peningkatan ketrampilan mendesain dan pewarnaan denga airbrush sudah dipraktekan dengan memberikan 
bantuan kompresor, spite airbrush untuk dapat meningkatkan kapasitas produksi.

\section{KEPUSTAKAAN}

Abidin, Zaenal. Usulan Perbaikan Tata Letak Fasilitas Produksi UKM Sentral Seragam. Jakarta, 2011.

Departemen Pembinaan Koperasi, Usaha Kecil dan Menengah Propinsi Bali, 2000. Laporan Perkembangan Usaha Kecil dan Menengah kabupaten Badung.

Fitiline, 2012, teknik Pewarnaan Batik Semprot atau Airbrush. Diakses online Nopember 2012

Nurmianto, 1998. Desain stasiun Kerja yang Sehat, Jakarta: Guna Widya

Rika Ampuh Hadiguna. 2009. Manajemen Pabrik: Pendekatan Sistem untuk Efisiensi dan Efektifitas. Jakarta: Bumi Aksara.

Setiani, S. 2013. Perbedaan Hasil jadi Kombinasi Pewarnaan Airbrush dan Block Printng Pada Dua Jenis kain Sutra. EJurnal Vol.2 No. 3. Fakultas Teknik Universitas Surabaya..

Sutalaksana,1999. Pengautran Stasiun Kerja yang Ergonomis Guna Meningkatkan Kenyamanan Kerja

Wignjosoebroto, Sritomo. Tata Letak Pabrik dan Pemindahan Bahan. Edisi Ketiga Cetakan Pertama. Guna Widya, Surabaya, 2000.

\section{UCAPAN TERIMAKASIH}

Melalui tulisan ini kami mengucapkan penghargaan yang setinggi-tingginya kepada Direktorat Pendidikan Tinggi (Dikti), Rektor Universitas Mahasaraswati Denpasar melalui LP2M Unmas dan Direktur Politeknik Negeri Bali melalui jurusan Teknik Mesin pada Laboratorium Mekanik yang telah memfasilitasi pelaksanaan program IbPE pada UD. Anugrah di desa Gelgel Kelungkung dan UD. Artha Darma di desa Sinabun Buleleng. Penulis juga menyampaikan penghargaan yang setinggi tingginya kepada ke dua mitra yang telah memberikan tempat dan fasilitas untuk pelaksanaan program IbPE, sehingga program yang dilaksanakan dapat berjalan efektif dan bermanfaat bagi pengerajin tenun baik endek dan songket Bali. 